\title{
Profilaxia do Prurido Causado pela Administração Subaracnóidea de Sufentanil: Efeitos do Droperidol, da Nalbufina, do Ondansetron e da Combinação Deles *
}

\section{Prevention of Itching after Spinal Sufentanil: Effects of Droperidol, Nalbuphine, Ondansetron and the Association of Them}

\author{
André Kolm ${ }^{1}$; Alexandre Alberto Fontana Ferraz, TSA ${ }^{1}$; Norma Sueli Pinheiro Módolo, TSA ${ }^{2}$; Fábio Ferrari, TSA ${ }^{3}$; \\ Eliana Marisa Ganem, TSA ${ }^{2}$; Geraldo Rolim Rodrigues Júnior, TSA ${ }^{3}$; Paulo do Nascimento Júnior, TSA ${ }^{2}$; \\ Giane Nakamura ${ }^{4}$; Lais Helena Camacho Navarro ${ }^{4}$; Rodrigo Moreira Lima ${ }^{5}$
}

\begin{abstract}
RESUMO
Kolm A, Ferraz AAF, Modolo NSP, Ferrari F, Ganem EM, Rodrigues Júnior $G R$, Nascimento Júnior $P$, Nakamura $G$, Navarro LHC, Lima RM - Profilaxia do Prurido Causado pela Administração Subaracnóidea de Sufentanil: Efeitos do Droperidol, da Nalbufina, do Ondansetron e da Combinação Deles
\end{abstract}

JUSTIFICATIVA E OBJETIVOS: O uso espinhal de opióides pode causar alguns efeitos indesejáveis, dentre os quais, o mais freqüente é o prurido que, apesar de sua baixa morbidade, pode proporcionar desconforto intenso ao paciente e prolongar o período de internação. O objetivo deste estudo foi avaliar diversas opções terapêuticas no tratamento profilático do prurido após administração de sufentanil por via subaracnóidea.

MÉTODO: Foram distribuídos de maneira aleatória, por sorteio, 100 pacientes a serem submetidos à intervenção cirúrgica não-obstétricas em cinco grupos, de acordo com o tratamento utilizado: controle (ausência de tratamento - C), droperidol 2,5 mg (D); nalbufina $10 \mathrm{mg}(\mathrm{N})$; associação dos medicamentos anteriores (DN) e ondansetron $8 \mathrm{mg}(\mathrm{O})$. O prurido foi avaliado quantitativamente 30 minutos, 1,2 , e 3 horas após a administração subaracnóidea de sufentanil.

RESULTADOS: Os grupos $C$ e $O$ apresentaram incidência significativamente maior de prurido em relação aos grupos $D, N$ e DN. Entretanto, não houve diferença significativa na necessidade de tratamento específico com naloxona entre os grupos tratados.

CONCLUSÕES: O tratamento profilático do prurido neste estudo, independentemente do fármaco utilizado, diminuiu sua

\footnotetext{
* Recebido do (Received from) Departamento de Anestesiologia da Faculdade de Medicina de Botucatu, Universidade Estadual de São Paulo (FMB - UNESP), Botucatu, SP

1. Anestesiologistas, Ex-Residentes do CET/SBA da FMB - UNESP

2. Professores Adjuntos da FMB - UNESP

3. Professores Assistentes Doutores da FMB - UNESP

4. Anestesiologistas e Pós-Graduandas do Programa de Pós-Graduação da FMB - UNESP

5. $\mathrm{ME}_{3}$ do CET/SBA da FMB - UNESP
}

Apresentado (Submitted) em 06 de julho de 2005

Aceito (Accepted) para publicação em 14 de dezembro de 2005

Endereço para correspondência (Correspondence to)

Dra. Norma Sueli Pinheiro Módolo

Distrito de Rubião Júnio

18618-970 Botucatu, SP

E-mail:nmodolo@fmb.unesp.br

(C) Sociedade Brasileira de Anestesiologia, 2006 intensidade e limitou a necessidade de tratamento específico com naloxona.

Unitermos: ANALGESIA: espinhal; ANALGÉSICOS, Opióides: sufentanil; ANTAGONISTAS: nalbufina; ANTIEMÉTICOS: droperidol, ondansetron; COMPLICAÇÕES: prurido

\section{SUMMARY}

Kolm A, Ferraz AAF, Modolo NSP, Ferrari F, Ganem EM, Rodrigues Júnior GR, Nascimento Júnior $P$, Nakamura G, Navarro LHC, Lima RM - Prevention of Itching after Spinal Sufentanil: Effects of Droperidol, Nalbuphine, Ondansetron and the Association of Them

BACKGROUND AND OBJECTIVES: Spinal opioids may cause some undesirable effects, the most frequent of which is itching. In spite of its low morbidity rate, itching may cause severe discomfort to patients in addition to prolonging hospital stay. This study aimed at evaluating different therapeutic options to prevent itching after spinal sufentanil.

METHODS: Participated in these study 100 patients scheduled for non-obstetric procedures, who were randomly distributed in five groups: control (no treatment - C); $2.5 \mathrm{mg}$ droperidol (D); 10 $m g$ nalbuphine (N); association of previous drugs (DN); and 8 $m g$ ondansetron (O). Pruritus was quantitatively evaluated at 30 minutes, 1, 2 and 3 hours after spinal sufentanil.

RESULTS: Groups $C$ and $O$ had significantly higher incidence of itching as compared to groups $D, N$ and $D N$. However, there has been no significant difference in the need for specific treatment with naloxone among groups.

CONCLUSIONS: Itching prevention in our study, regardless of the drug used, has decreased its severity and has limited the need for specific treatment with naloxone.

Key Words: ANALGESIA: spinal; ANALGESICS, Opioids: sufentanil; ANTAGONISTS: nalbuphine; ANTIEMETICS: droperidol, ondansetron; COMPLICATIONS: itching

\section{INTRODUÇÃO}

$\mathrm{O}$ uso de opióides espinhais aumentou consideravelmente nos últimos anos, possibilitando analgesia eficiente e segura além de potencialização da ação dos anestésicos locais ${ }^{1}$. Contudo, alguns efeitos colaterais têm limitado o seu uso, sendo que os mais freqüentes são o prurido, a náusea, o vômito e a retenção urinária. Esses efeitos indesejáveis, embora de pouca morbidade, proporcionam desconforto aos pacientes e podem prolongar o período de internação ${ }^{2,3}$. 
O sufentanil, opióide agonista do receptor $\mu$ de alta lipossolubilidade e potência, tem sido amplamente utilizado devido à excelente potencialização dos anestésicos locais administrados no neuro-eixo e ao pequeno risco de depressão respiratória tardia nas doses empregadas. No entanto, o prurido após a injeção do sufentanil é freqüente e, algumas vezes, intenso ${ }^{4}$.

Vários tratamentos têm sido propostos para prevenir ou reverter este efeito indesejável. A naloxona, fármaco antagonista opióide, seria a escolha mais apropriada. Entretanto, o seu emprego tem sido associado à piora da qualidade da analgesia, além de efeitos cardiovasculares indesejáveis em alguns casos ${ }^{5,6}$

O propofol também tem sido sugerido como opção terapêuti$\mathrm{ca}^{7,8}$, mas sua eficácia como antipruriginoso é controversa ${ }^{9}$ e seu custo elevado. Outra opção visando o mesmo efeito seria o droperidol, antagonista dopaminérgico ${ }^{10,11}$, cujo uso foi também questionado ${ }^{12}$.

A nalbufina, agonista $\kappa$ - antagonista $\mu$, tem sido utilizada para este fim e teve sua eficácia comprovada por vários autores como agente terapêutico na reversão do prurido causado após o uso de opióides no neuro-eixo ${ }^{13}$.

Mais recentemente, o ondansetron, um antagonista da serotonina, vem sendo empregado com sucesso no tratamento do prurido induzido pela colestase e pela morfina ${ }^{14-17}$.

O objetivo deste estudo foi verificar a eficácia do droperidol, da nalbufina, da associação dos dois fármacos e do ondansetron na profilaxia do prurido causado pela administração de sufentanil por via subaracnóidea.

\section{MÉTODO}

Após aprovação pelo Comitê de Ética em Pesquisa Humana do Hospital das Clínicas da Faculdade de Medicina de Botucatu, 100 pacientes estado físico ASA I e II, de ambos os sexos e com idade entre 15 e 70 anos, submetidos à anestesia subaracnóidea para intervenção cirúrgica não-obstétrica foram incluídos neste estudo de maneira prospectiva e aleatória por sorteio. Foram excluídos os pacientes que apresentavam doenças dermatológicas que cursam com prurido, os que fizeram uso de opióides nas antecedentes 24 horas e os casos em que houve falha ou recusa pelo paciente para a realização do bloqueio.

A medicação pré-anestésica consistiu em diazepam (10 mg) por via oral, uma hora antes do procedimento. A monitorização, padronizada para todos os pacientes, foi composta por oxímetro de pulso, cardioscópio na derivação $D_{\|}$e pressão arterial não-invasiva. Após punção venosa periférica, procedeu-se a infusão de solução de Ringer com lactato de sódio na velocidade apropriada para manter a estabilidade hemodinâmica.

A punção raquidiana foi realizada com agulha tipo Quincke $25 \mathrm{G}$ nos interespaços $L_{2}-L_{3}$ ou $L_{3}-L_{4} e$, após refluxo de líquor, foram injetados $15 \mathrm{mg}$ de bupivacaína hiperbárica e logo após $10 \mu \mathrm{g}$ de sufentanil, com a utilização de seringas separadas.

Revista Brasileira de Anestesiologia

Vol. 56, № 1, Janeiro - Fevereiro, 2006
Após o início da instalação do bloqueio sensitivo, os pacientes foram distribuídos de maneira aleatória em cinco grupos de acordo com o medicamento administrado: controle (ausência de tratamento, C), droperidol 2,5 mg (D), nalbufina 10 $\mathrm{mg}(\mathrm{N})$, droperidol $2,5 \mathrm{mg}$ associado a nalbufina $10 \mathrm{mg}(\mathrm{DN}) \mathrm{e}$ ondansetron $8 \mathrm{mg}(\mathrm{O})$. Os fármacos, nos quatro últimos grupos, foram administrados antes do aparecimento do prurido.

Foram então registrados, 30 minutos e a cada hora após a injeção do sufentanil até um total de três horas, os seguintes parâmetros: prurido, sedação, náusea e vômitos. A avaliação quantitativa destes parâmetros foi realizada de acordo com as escalas apresentadas na tabela I.

Tabela I - Escalas de Avaliação

\begin{tabular}{llll}
\hline & Prurido & Sedação & Náusea/Vômito \\
\hline 0 & Ausente & Acordado & Ausente \\
1 & $\begin{array}{l}\text { Leve, sem necessidade } \\
\text { de coçar }\end{array}$ & $\begin{array}{l}\text { Sonolento, responde } \\
\text { ao chamado }\end{array}$ & Náusea \\
2 & $\begin{array}{l}\text { Moderado, necessidade } \\
\text { de coçar ocasional }\end{array}$ & $\begin{array}{l}\text { Sonolento, responde } \\
\text { ao toque leve }\end{array}$ & Vômito \\
3 & $\begin{array}{l}\text { Intenso, necessidade } \\
\text { de coçar constante }\end{array}$ & $\begin{array}{l}\text { Intensa, responde } \\
\text { ao estímulo doloroso }\end{array}$ & \\
4 & Refratário a naloxona & & \\
\hline
\end{tabular}

Considerou-se a ocorrência de hipoxemia quando a saturação periférica de oxigênio diminuiu abaixo de $90 \%$, situação que foi corrigida com a administração de oxigênio ( 3 L. min $^{-1}$ ) por meio de máscara facial. A ocorrência de hipotensão arterial (diminuição da pressão arterial sistólica maior que 30\% em relação à pressão inicial) foi tratada com a administração de solução de Ringer com lactato de sódio e efedrina, 5 a 10 mg por via venosa. Em todos os pacientes, para o alívio da dor pós-operatória, foram empregados $20 \mathrm{mg}$ de tenoxicam, por via venosa.

A análise estatística das variáveis estudadas foi realizada com a ajuda do programa Statview ${ }^{\circledR} 5.2$ (SPSS, Inc., San Raphael, CA, EUA). Para comparação entre grupos foi usado o teste de Kruskal-Wallis. O tamanho da amostra foi calculado para um poder de $80 \%$ com a ajuda do programa SigmaStat ${ }^{\circledR} 2.03$ (SPSS, Inc., San Raphael, CA, EUA) e valor de $p<0,05$ foi considerado significativo.

\section{RESULTADOS}

Os grupos em estudo foram comparáveis em relação aos parâmetros demográficos, tipo de procedimento cirúrgico e estado físico. Não foram observadas diferenças estatísticas significativas entre os grupos quanto à incidência de hipotensão arterial, hipoxemia, náusea e vômitos. Quanto à incidência de prurido nos diferentes momentos estudados, houve diferença estatística significativa entre o grupo controle e o grupo tratado com ondansetron em relação aos demais grupos na primeira e na segunda hora, com menor incidência nos grupos tratados com droperidol, nalbufina e com a associação dos dois fármacos $(p<0,05)$ (Figura 1). 
Aavaliação quantitativa do prurido realizada pela necessidade do tratamento específico com naloxona mostrou intensidade menor nos grupos que receberam tratamento profilático em relação ao grupo controle, independentemente do fármaco utilizado $(p<0,01)$ (Figura 2).

Após a administração dos fármacos estudados, a presença de sedação foi menor no grupo controle e no grupo tratado com ondansetron em todos os momentos estudados $(p<$ $0,05)$. Nos grupos tratados com droperidol ou a associação de droperidol com nalbufina, todos os pacientes apresentaram sedação de intensidade variável (Figura 1).

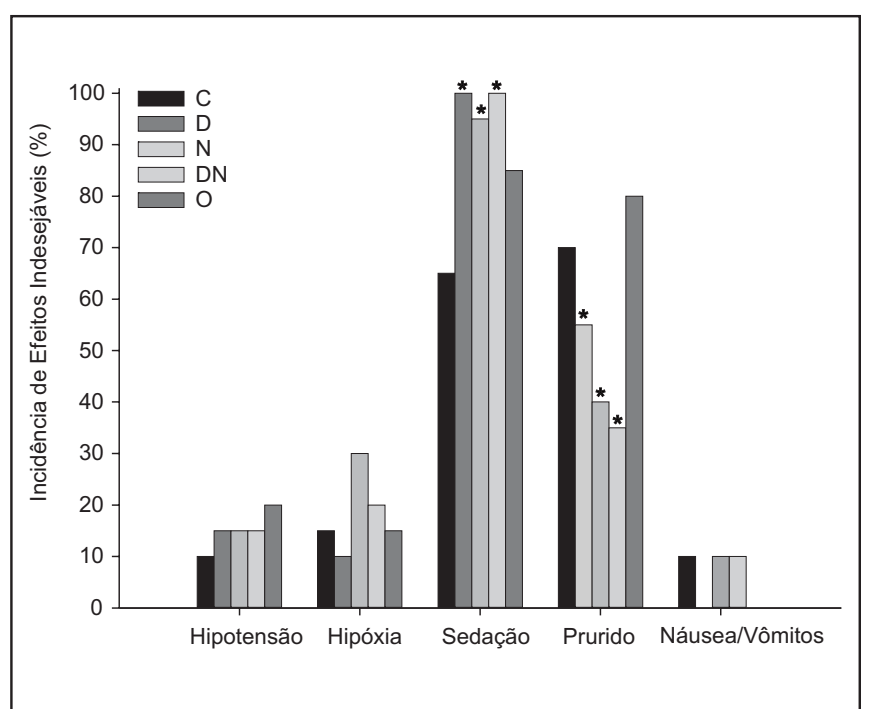

Figura 1 - Incidência de Efeitos Indesejáveis segundo o Grupo Estudado.

$C=$ controle $; \mathrm{D}=$ droperidol; $\mathrm{N}=$ nalbufina; $\mathrm{DN}=$ associação de droperidol e nalbufina; $\mathrm{O}=$ ondansetron. Nos grupos $\mathrm{D}$ e $\mathrm{O}$ nenhum paciente apresentou náusea/vômito

* diferença significativa em relação ao grupo controle

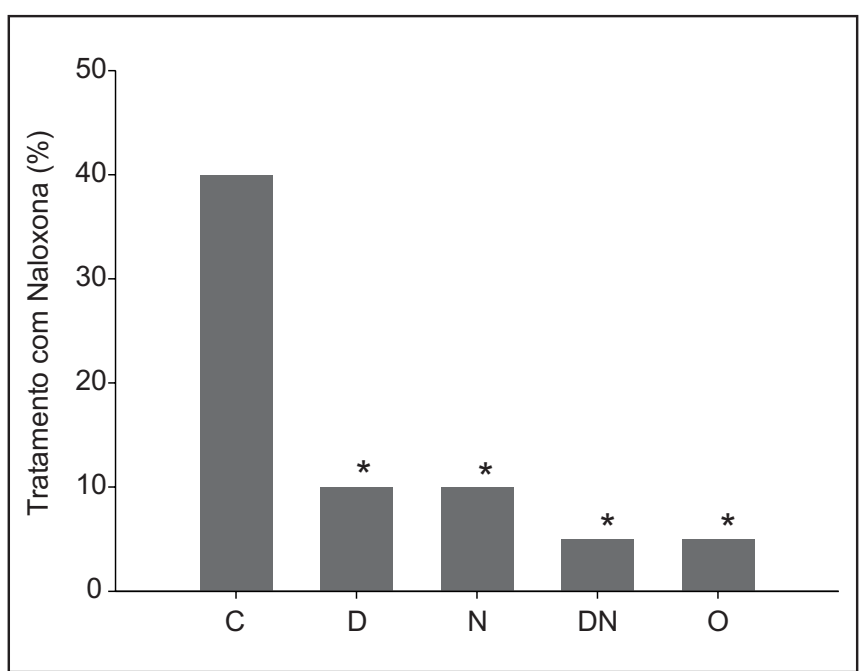

Figura 2 - Necessidade de Tratamento Específico com Naloxona segundo o Fármaco Anti-Pruriginoso Administrado.

$\mathrm{C}=$ controle; $\mathrm{D}=$ droperidol; $\mathrm{N}$ = nalbufina; $\mathrm{DN}=$ associação de droperidol e nalbufina; $\mathrm{O}=$ ondansetron

${ }^{*} \mathrm{p}<0,01$
A freqüência de utilização de naloxona foi de $40 \%$ no grupo controle, $10 \%$ no grupo tratado com droperidol, $10 \%$ no grupo tratado com nalbufina, $5 \%$ no grupo tratado com a associação de droperidol e nalbufina e $5 \%$ no grupo tratado com ondansetron, mostrando que o prurido, independentemente da sua incidência, foi de menor intensidade nos grupos tratados em relação ao grupo controle.

\section{DISCUSSÃO}

O efeito colateral mais comum relativo ao emprego dos opióides por via espinhal é o prurido, embora a forma grave ocorra em somente $1 \%$ dos pacientes ${ }^{18}$. O mecanismo responsável pelo seu desenvolvimento não está plenamente esclarecido. Estudos em animais serviram de base para o conceito de que exista um "centro do prurido" localizado inferiormente na medula e indicando que o núcleo do trigêmeo está envolvido neste mecanismo ${ }^{19}$.

O prurido pode ser generalizado, mas é mais freqüente na face, pescoço e parte superior do tórax. Na face, é mais comum aparecer em áreas inervadas pelo trigêmeo ${ }^{19}$, indicando migração cefálica do fármaco no líquor e interação com o núcleo deste nervo, que por sua vez possui receptores opióides, também presentes em suas raízes nervosas ${ }^{20,21}$. Este movimento rostral dos opióides em direção às cisternas basais facilita o acesso ao núcleo do trigêmeo ${ }^{9}$.

Alguns outros mecanismos aventados para o aparecimento do prurido se baseiam na liberação de histamina, taquicininas e interleucinas, substâncias que não causam prurido por si só, mas possuem atividade pró-inflamatória que pode sensibilizar as terminações nervosas e levar ao prurido. Além disso, a 5-hidroxitriptamina (serotonina) pode ser uma das substâncias reguladoras do prurido por ação direta em seus receptores, mecanismo observado em pacientes com colestase ${ }^{22}$.

No presente estudo, a utilização da associação de droperidol e nalbufina foi a que mais reduziu a incidência de prurido nos momentos estudados após a administração do sufentanil, com incidência de $5 \%$ aos 30 minutos, $25 \%$ na primeira hora, $15 \%$ na segunda hora e $5 \%$ na terceira hora, embora estes resultados não tenham apresentado diferença estatística em relação aos demais grupos. Este efeito se deve provavelmente ao fato de os mecanismos de ação destes dois fármacos serem distintos, o que contribui para o sucesso do tratamento.

O grupo tratado com droperidol apresentou incidência de prurido de $25 \%$ aos 30 minutos, $35 \%$ na primeira hora, $30 \%$ na segunda hora e $30 \%$ na terceira hora. Horta e col. ${ }^{10}$ demonstraram a eficácia do droperidol, na dose $2,5 \mathrm{mg}$, em reduzir a incidência de prurido após a utilização de opióide por via subaracnóidea. Doses maiores ou iguais a $5 \mathrm{mg}$ não aumentaram a efetividade no tratamento desta complicação e a baixa incidência de sedação não comprovou ser este o mecanismo pelo qual o droperidol inibe o prurido.

O droperidol liga-se principalmente aos receptores dopaminérgicos D2, mas também apresenta atividade junto aos receptores adrenérgicos alfa-1 e alfa-2, serotoninérgicos $5 \mathrm{HT}-2$, histaminérgicos $\mathrm{H}-1$ e receptores opióides $\mu^{11}$. Ainda 
não se pode afirmar com certeza se algum destes receptores está envolvido na modulação do prurido pelo droperidol, embora tal fato tenha sido demonstrado em alguns estudos ${ }^{10,11}$. O grupo tratado com nalbufina apresentou incidência de prurido de $30 \%$ aos 30 minutos, $25 \%$ na primeira hora, $20 \%$ na segunda hora e $20 \%$ na terceira hora. O melhor resultado em relação ao grupo controle é provavelmente devido ao seu efeito antagonista nos receptores $\mu^{13}$.

O grupo tratado com ondansetron apresentou incidência de prurido semelhante ao grupo controle em todos os momentos estudados. Aintensidade do prurido nesse grupo foi comparável aos outros tratamentos utilizados com base na necessidade de tratamento com naloxona tendo, porém, a vantagem de menor sedação devido ao seu mecanismo de ação (inibição seletiva dos receptores $5-\mathrm{HT} 3)^{17}$.

\section{Prevention of Itching after Spinal Sufentanil: Effects of Droperidol, Nalbuphine, Ondansetron and the Association of Them}

André Kolm, M.D.; Alexandre Alberto Fontana Ferraz, TSA, M.D.; Norma Sueli Pinheiro Módolo, TSA, M.D.; Fábio Ferrari, TSA, M.D.; Eliana Marisa Ganem, TSA, M.D.;Geraldo Rolim Rodrigues Júnior, TSA, M.D.; Paulo do Nascimento Júnior, TSA, M.D.; Giane Nakamura, M.D.; Lais Helena Camacho Navarro, M.D.; Rodrigo Moreira Lima, M.D.

\section{INTRODUCTION}

Spinal opioids administration has increased in recent years, allowing effective and safe analgesia, in addition to improving local anesthetics action ${ }^{1}$. However, some side effects have limited its use, among them itching, nausea, vomiting and urinary retention. These undesirable effects, although with low morbidity rate, bring discomfort to patients and may prolong hospital stay ${ }^{2,3}$.

Sufentanil, highly liposoluble and potent $\mu$ receptor agonist, has been widely used due to the excellent improvement of local anesthetics administered to the neuraxis and to the low risk of late respiratory depression. However itching after sufentanil is common and sometimes severe ${ }^{4}$.

Different treatments have been proposed to prevent or treat this undesirable effect. Naloxone, opioid antagonist drug, would be the best choice. However its use has been associated to lower analgesia quality, in addition to undesirable cardiovascular effects in some cases ${ }^{5,6}$.

Propofol has also been suggested as therapeutic option ${ }^{7,8}$, but its effectiveness against itching is controversial ${ }^{9}$ and its cost is high. Another option would be droperidol, dopaminergic antagonist ${ }^{10,11}$, which use has also been questioned $^{12}$.
Nalbuphine, $\kappa$ agonist $-\mu$ antagonist, has been used for this end and had its efficacy proven by different authors as therapeutic agent in spinal opioids-induced itching ${ }^{13}$.

More recently ondansetron, serotonin antagonist, is being successfully used to treat cholestasis and morphine-induced itching ${ }^{14-17}$.

This study aimed at evaluating the efficacy of droperidol, of nalbuphine, of the association of both, and of ondansetron to prevent spinal sufentanil-induced itching.

\section{METHODS}

After the Human Research Ethics Committee, Hospital das Clínicas, Faculdade de Medicina, Botucatu approval, participated in this prospective randomized study 100 patients of both genders, aged 15 to 70 years, physical status ASA I and II, submitted to spinal anesthesia for non-obstetric procedures. Exclusion criteria were dermatologic diseases with itching, use of opioids 24 hours before surgery and when there was failure or patients refused the spinal anesthesia. Patients were premedicated with oral diazepam $(10 \mathrm{mg})$ one hour before procedure. Standardized monitoring for all patients consisted of pulse oximetry, cardioscope at $D_{\text {II }}$ lead and noninvasive blood pressure. Lactated Ringer's solution was infused after peripheral venous puncture, at the adequate rate to maintain hemodynamic stability.

Spinal puncture was performed with 25G Quincke needle in $L_{2}-L_{3}$ or $L_{3}-L_{4}$ interspace and, after CSF reflux, $15 \mathrm{mg}$ hyperbaric bupivacaine and soon after $10 \mu \mathrm{g}$ sufentanil were injected with separate syringes.

After sensory block installation, patients were randomly distributed in five groups: control (no treatment - C); $2.5 \mathrm{mg}$ droperidol (D); $10 \mathrm{mg}$ nalbuphine $(\mathrm{N})$; 2.5 droperidol associated to $10 \mathrm{mg}$ nalbuphine (DN); and $8 \mathrm{mg}$ ondansetron (O). Drugs were administered before the onset of itching.

The following parameters were recorded at 30 minutes, 1, 2 and 3 hours after sufentanil injection: itching, sedation, nausea and vomiting. Parameters were quantitatively evaluated according to scales shown in table I.

Table I - Evaluation Scales

\begin{tabular}{llll}
\hline & Itching & Sedation & Nausea/Vomiting \\
\hline 0 & Absent & Awaken & Absent \\
1 & $\begin{array}{l}\text { Mild, not requiring } \\
\text { scratching }\end{array}$ & $\begin{array}{l}\text { Sleepy, responding } \\
\text { to call }\end{array}$ & Nausea \\
2 & $\begin{array}{l}\text { Moderate, occasional } \\
\text { scratching }\end{array}$ & $\begin{array}{l}\text { Sleepy, responding } \\
\text { to mild touch }\end{array}$ & Vomiting \\
3 & $\begin{array}{l}\text { Severe, constant need } \\
\text { for scratching }\end{array}$ & $\begin{array}{l}\text { Deep, responding } \\
\text { to painful stimulation }\end{array}$ & \\
4 & Refratory to naloxone & & \\
\hline
\end{tabular}

Hypoxemia was defined as peripheral oxygen saturation below $90 \%$ and was corrected with $3 \mathrm{~L}$ oxygen per minute under facial mask. Hypotension (systolic blood pressure below $30 \%$ of baseline pressure) was treated with 5 to $10 \mathrm{mg}$ of ephedrine. Intravenous $20 \mathrm{mg}$ tenoxicam were administered to all patients for postoperative pain relief. 
Statistical analysis was performed with the aid of the program Statview ${ }^{\circledR} 5.2$ (SPSS, Inc., San Raphael, CA, EUA). Kruskal-Wallis test was used to compare among groups. Sample size was calculated for a power of $80 \%$ (SigmaStat ${ }^{\circledR}$ 2.03 - SPSS, Inc., San Raphael, CA, EUA) considering significant $p<0.05$.

\section{RESULTS}

Groups were comparable in demographics, surgical procedure and physical status. There were no statistically significant differences among groups in hypotension, hypoxemia, nausea and vomiting. As to itching, there has been statistically significant difference between control and ondansetron groups as compared to remaining groups in the first and second hours, with lower incidence in groups treated with droperidol, nalbuphine and the association of both drugs $(p<$ 0.05) (Figure 1).

Quantitative itching evaluation by the need for specific treatment with naloxone has shown lower intensity in treated groups as compared to control, regardless of the drug $(p<$ 0.01) (Figure 2).

After drugs administration, sedation rate was lower for the control group and the ondansetron group in all studied moments $(p<0.05)$. In groups treated with droperidol or the association of droperidol and nalbuphine, all patients presented sedation of different intensities (Figure 1).

Naloxone was used in $40 \%$ of control group, $10 \%$ of droperidol group, $10 \%$ of nalbuphine group, $5 \%$ of droperidol/nalbuphine group and $5 \%$ of ondansetron group, showing that itching, regardless of its incidence, was less severe in treated groups as compared to control group.

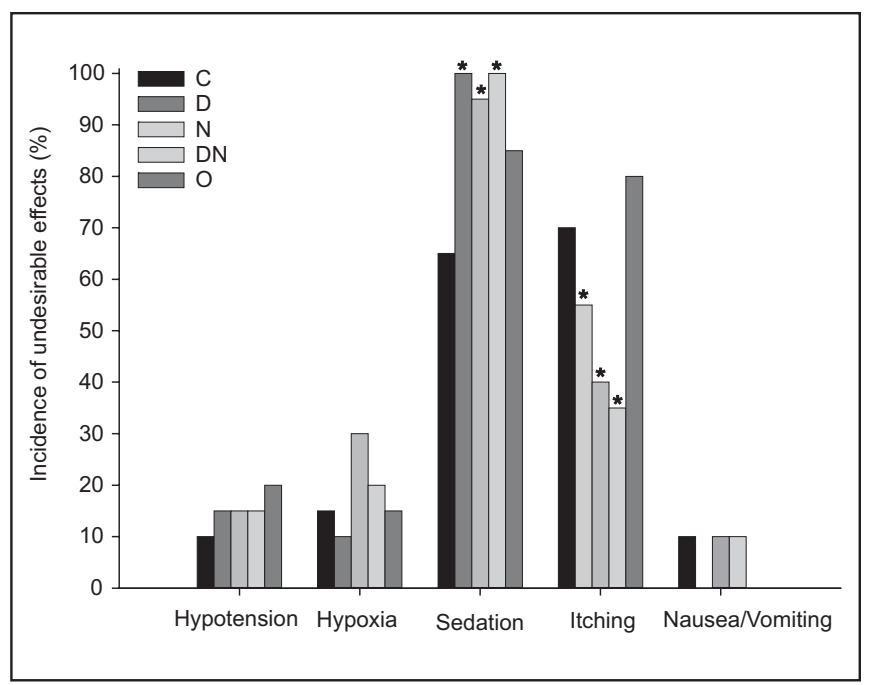

Figure 1 - Incidence of Undesirable Effects According to the Studied Group

$\mathrm{C}=$ control; $\mathrm{D}=$ droperidol; $\mathrm{N}=$ nalbuphine; $\mathrm{DN}=$ droperi$\mathrm{dol} /$ nalbuphine association; $\mathrm{O}=$ ondansetron. No group $\mathrm{D}$ and O patient presented nausea/vomiting

* statistically diferent from control group

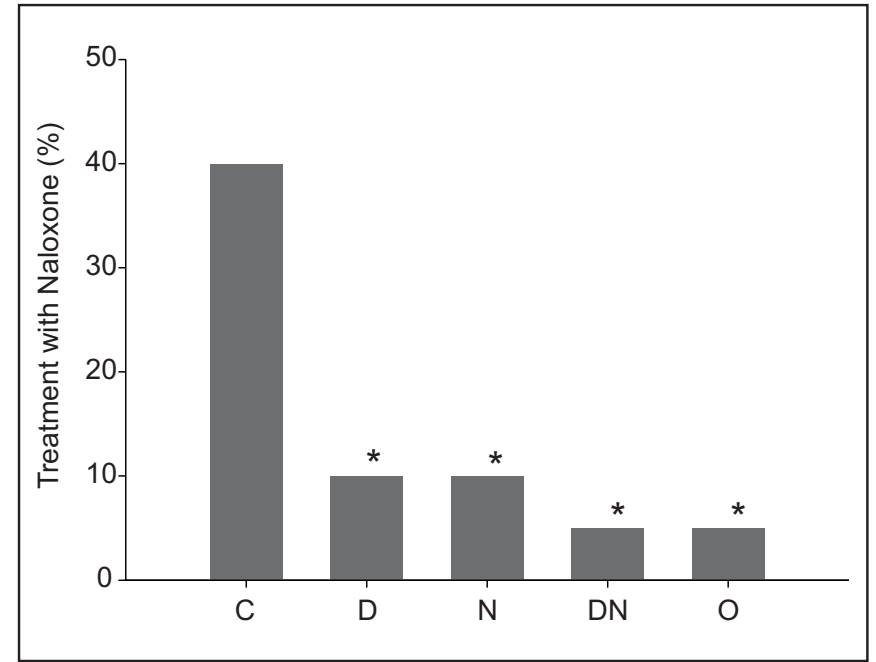

Figure 2 - Need for Specific Treatment with Naloxone according to Anti-Itching Drug Used.

$\mathrm{C}=$ control; $\mathrm{D}=$ droperidol; $\mathrm{N}=$ nalbuphine; $\mathrm{DN}=$ droperidol/nalbuphine association; $\mathrm{O}=$ ondansetron * $p<0.01$

\section{DISCUSSION}

Most common spinal opioids side effect is itching, although its severe presentation is only seen in $1 \%$ of patients ${ }^{18}$. Its action mechanism is still to be fully explained. Animal studies were the basis for the concept of an "itching center" located inferiorly in the spinal cord and indicating that the trigeminal nucleus would be involved in this mechanism ${ }^{19}$.

Itching may be generalized but is most common on face, neck and upper chest. On the face, it is more common on trigeminal-nerve innervated areas ${ }^{19}$, indicating cephalad CSF migration and interaction with the nucleus of this nerve, which in turn has opioid receptors also present on its nervous roots ${ }^{20,21}$. This rostral movement of opioids toward baseline cisterns helps the access to the trigeminal nucleus ${ }^{9}$.

Some other mechanisms suggested for itching are based on histamine, tachycinine and interleukin release, substances which promote itching by themselves, but which have pro-inflammatory activity able to sensitize nervous terminations and lead to itching. In addition, 5-hydroxitriptamine (serotonin) may be an itching regulating substance by directly acting on its receptors, mechanism observed in cholestasis patients ${ }^{22}$.

In our study, the association of droperidol and nalbuphine was the most effective in decreasing itching after sufentanil administration, with $5 \%$ incidence at 30 minutes, $25 \%$ at one hour, $15 \%$ at two hours and $5 \%$ at three hours, although these results were not statistically different as compared to remaining groups. This effect was probably due to the fact that action mechanisms of these two drugs are different, thus contributing to the success of the treatment. 
The droperidol group had $25 \%$ itching at 30 minutes, $35 \%$ at one hour, $30 \%$ at two hours and $30 \%$ at three hours. Horta et al. ${ }^{10}$ have shown the efficacy of $2.5 \mathrm{mg}$ droperidol in decreasing itching alter spinal opioid. Doses higher than or equal to 5 mg have not increased the effectiveness of the treatment and mild sedation has not confirmed that this is the mechanism through which droperidol inhibits itching.

Droperidol is primarily bound to D2 dopaminergic receptors, but also acts on alpha ${ }_{1}$ and alpha ${ }_{2}$ adrenergic, 5HT-2 serotoninergic, $\mathrm{H}-1$ histaminergic and $\mu$ opioid receptors ${ }^{11}$. One cannot yet state that some of these receptors are involved with itching modulation by droperidol, although such fact has been shown by some studies ${ }^{10,11}$.

The nalbuphine group had $30 \%$ itching at 30 minutes, $25 \%$ at one hour, $20 \%$ at two hours and $20 \%$ at three hours. Better results as compared to control group are probably due to its antagonist effect on $\mu$ receptors ${ }^{13}$.

The ondansetron group had itching incidence similar to control group in all studied moments. Itching severity in this group was comparable to other treatments based on the need for naloxone, however with the advantage of less sedation due to its action mechanism (selective 5-HT3 receptors inhibition) ${ }^{17}$.

\section{REFERÊNCIAS - REFERENCES}

01. Yaksh TL, Hammond DL - Spinal opiate analgesia: characteristics and principles of action. Peripheral and central pathways in pain. Pain, 1981;11:293-346.

02. Bromage PR, Camporesi EM, Durant PA et al - Nonrespiratory side effects of epidural morphine. Anesth Analg, 1982;61: 490-495.

03. Chaney MA - Side effects of intrathecal and epidural opioids. Can J Anaesth, 1995;42:891-903.

04. Morgan M - The rational use of intrathecal and extradural opioids. Br J Anaesth, 1989;63:165-188.

05. Azar I, Turndorf H - Severe hypertension and multiple atrial premature contractions following naloxone administration. Anesth Analg, 1979;58:524-525.

06. Gowan JD, Hurtig JB, Fraser RA et al - Naloxone infusion after prophylactic epidural morphine: effects on incidence of postoperative side-effects and quality of analgesia. Can J Anaesth, 1988;35:143-148.

07. Borgeat A, Wilder-Smith OH, Saiah M et al - Subhypnotic doses of propofol relieve pruritus induced by epidural and intrathecal morphine. Anesthesiology, 1992;76:510-512.

08. Nunes RR - Prevenção do prurido causado por morfina peridural com doses sedativas de propofol. Rev Bras Anestesiol, 1997;47:29-31.

09. Warwick JP, Kearns CF, Scott WE - The effect of subhypnotic doses of propofol on the incidence of pruritus after intrathecal morphine for caesarean section. Anaesthesia, 1997;52: 270-275.

10. Horta BL, Horta ML - Inhibition of epidural morphine-induced pruritus by intravenous droperidol. Reg Anesth, 1993;18: 118-120.

11. Horta ML, Ramos L, Goncalves Zda R et al - Inhibition of epidural morphine-induced pruritus by intravenous droperidol. The effect of increasing the doses of morphine and of droperidol. Reg Anesth, 1996;21:312-317.

Revista Brasileira de Anestesiologia

Vol. 56, № 1, Janeiro - Fevereiro, 2006
12. Carvalho JC, Mathias RS, Senra WG et al - Systemic droperidol and epidural morphine in the management of postoperative pain. Anesth Analg, 1991;72:416.

13. Penning JP, Samson B, Baxter AD - Reversal of epidural morphine-induced respiratory depression and pruritus with nalbuphine. Can J Anaesth, 1988;35:599-604.

14. Schworer H, Ramadori G - Improvement of cholestatic pruritus by ondansetron. Lancet, 1993;341:(8855):1277.

15. Raderer M, Muller C, Scheithauer W - Ondansetron for pruritus due to cholestasis. N Eng J Med, 1994;330:1540.

16. Arai L, Stayer S, Schwartz R et al - The use of ondansetron to treat pruritus associated with intrathecal morphine in two paediatric patients. Paed Anaesth, 1996;6:337-339.

17. Owczarzack Jr D, Oliveira Filho GR, Ghellar MR et al Prevalência de prurido durante tratamento profilático de náuseas e vômitos induzidos por morfina peridural no pós-operatório de cesarianas: comparação entre ondansetron e metoclopramida. Rev Bras Anestesiol, 1999;49:240-243.

18. Krause L, Shuster S - Mechanism of action of antipruritic drugs. Br Med J Clin Res Ed, 1983;287:(6400):1199-1200.

19. Hu JW, Dostrovsky JO, Sessle BJ - Functional properties of neurons in cat trigeminal subnucleus caudalis (medullary dorsal horn). I. Responses to oral-facial noxious and nonnoxious stimuli and projections to thalamus and subnucleus oralis

20. Presynaptic excitability changes produced in brain stem endings of tooth pulp afferents by raphe and other central and peripheral influences. J Neurophysiol, 1981;45:173-192.

21. Ballantyne JC, Loach AB, Carr DB - Itching after epidural and spinal opiates. Pain, 1988;33: 149-160.

22. Snyder $\mathrm{SH}$ - Opiate receptors in the brain. $\mathrm{N}$ Eng $\mathrm{J}$ Med, 1977;296:266-271.

23. Greaves MW, Wall PD - Pathophysiology of itching. Lancet, 1996;348:(9032):938-940

\section{RESUMEN}

Kolm A, Ferraz AAF, Modolo NSP, Ferrari F, Ganem EM, Rodrigues Júnior GR, Nascimento Júnior P, Nakamura G, Navarro LHC, Lima RM - Profilaxis del Prurito Inducido por la Administración Subaracnoidea de Sufentanil: Influencia do Droperidol, da Nalbufina, do Ondansetron y da Combinacion De Elles

JUSTIFICATIVA Y OBJETIVOS: EI USo espinal de opioides puede ser causa de efectos indeseables, entre los que el prurito es el más frecuente y a pesar de su escasa morbilidad puede ser causa de intenso desconfort y prolongar el tiempo de internación. El objetivo de este estudio es evaluar diferentes opciones terapéuticas para la prevención del prurito que ocurre después de la administración subaracnoidea de sufentanil.

MÉTODO: Cien pacientes que iban a recibir cirugías no obstétricas fueron divididos aleatoriamente (sorteo) en 5 grupos de acuerdo al tratamiento preventivo usado: control (sin tratamiento, grupo C); droperidol 2,5 mg (grupo D); nalbufina 10 mg (grupo N); asociación de los medicamentos anteriores (grupo DN) y ondansetron $8 \mathrm{mg}$ (grupo O). El prurito fue evaluado en forma cuantitativa 30 minutos, 1, 2 y 3 horas después de la administración subaracnoidea de sufentanil.

RESULTADOS: Los grupos C y O presentaron incidencia de prurito significativamente mayor comparados con los grupos $D$, $N$ y DN. No obstante, no hubo diferencia entre los grupos en relación al uso de naloxona como tratamiento específico.

CONCLUSIONES: EI tratamiento preventivo del prurito usado en este estudio, independiente del fármaco empleado, disminuyó la intensidad y limitó la necesidad de tratamiento con naloxona. 